Utah State University

DigitalCommons@USU

1960

\title{
Distance From the Apiary as a Factor in Alfalfa Pollination
}

M. D. Levin

George E. Bohart

Utah State University

William P. Nye

Utah State University

Follow this and additional works at: https://digitalcommons.usu.edu/piru_pubs

Part of the Entomology Commons

\section{Recommended Citation}

Levin, M. D., G. E. Bohart, and W. P. Nye. 1960. Distance From the Apiary as a Factor in Alfalfa Pollination. Jour. Econ. Ent. 53(1): 56-60.

This Article is brought to you for free and open access by the Pollinating Insects Research Unit at DigitalCommons@USU. It has been accepted for inclusion in All PIRU Publications by an authorized administrator of DigitalCommons@USU. For more information, please contact digitalcommons@usu.edu.

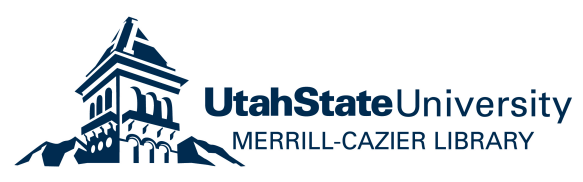



Table 1.-Average number of bees per square yard at increasing distances from the apiary on two 5-acre plots at Fielding, Utah, 1950.

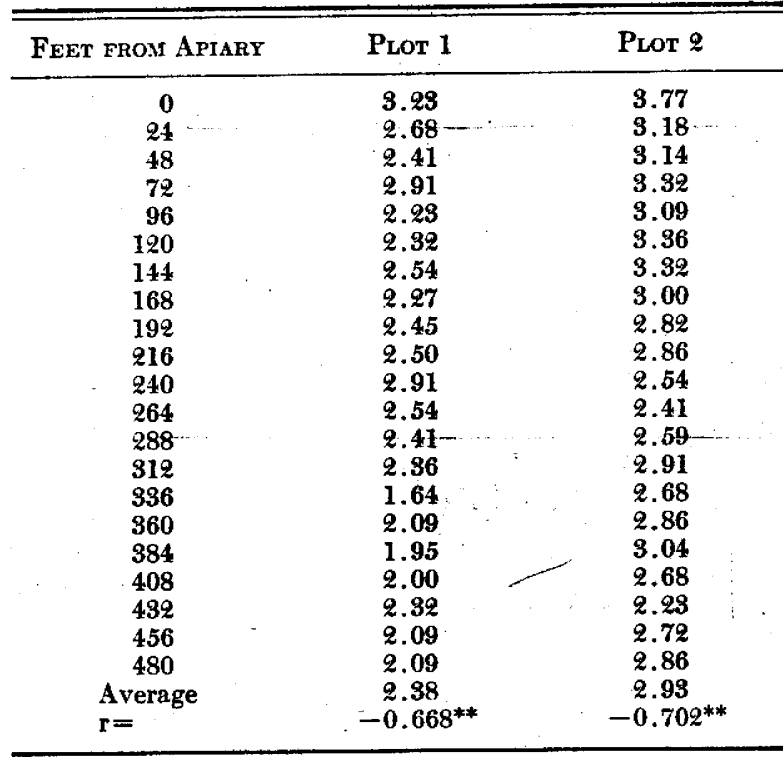

* Significant at $5 \%$ level.

** Significant at $1 \%$ level.

two crops. Furthermore, the variable results with red clover indicate that more work on that crop is needed to measure some of the factors responsible for observed differences in yields at various distances from bee colonies.

Several experiments have been conducted in northern Utah alfalfa fields to determine the effect on bee populations of increasing distances from apiaries.

Fieldivg, Utah.-Observations on 150 acres of seed alfalfa in a cooperative study of alfalfa-insect control and pollination carried out in 1950 revealed highly significant negative correlations between bee populations and their distances from the hives (table 1). The average bee population on this field was relatively high, ranging from 2.4 to 2.9 bees per square yard. Counts were made on two plots at 24 -foot intervals up to 480 feet away from a group of 232 colonies. These counts were made 5 days per week for 6 weeks. The data in table 1 represent the seasonal averages at each distance. Data from the field margins were deleted in these calculations to eliminate the influence of greater bloom on plants growing there.

Although the percentages of open flowers tripped at the bee-counting stations showed no trends, and seed yields were not measured in relation to distance from the colonies, the changes in bee population justified more detailed studies.

Newtox, Utar. - An experiment was conducted on a rectangular 14-acre field of alfalfa at Newton, Utah, in 1951. The primary objective was to determine whether within a distance of 600 feet alfalfa-seed yields and bee populations would be influenced by the distance from colonies of honey bees.

Methods.-One hundred colonies were placed in a double row across the middle of the field. Parallel to the line of bees, the field was divided into ten 100 -foot sampling belts. Ten-foot buffer strips were left between each belt and at each end of the field (fig. 1). The field was

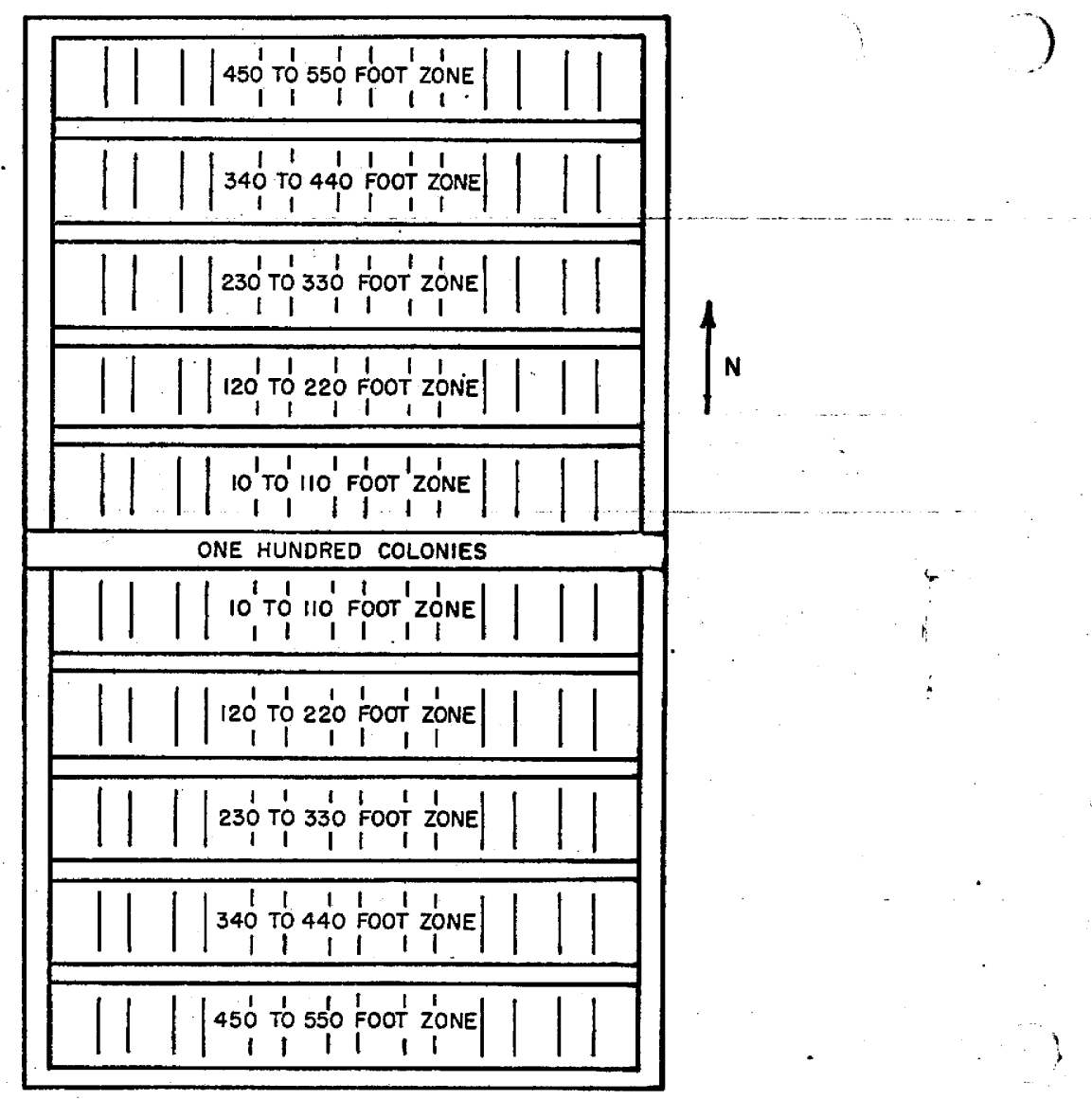

Fig. 1.-Diagram of experimental alfalfa seed field, Sewton, Utah, 1951.

further divided into eight 20 -foot strips at right angles"to the line of colonies, thus providing subplots for sampling purposes. This arrangement provided two replications for directions and five distance treatments with eight areas for sampling across each whole plot.

Types of Data.-The data were taken by random sampling of all the subplots during the season. The numbers of honey bees and wild bees per square yard and the per cent of flowers tripped were each determined from 13 samplings and the per cent of flowers forming pods from two samplings. Seed yields were determined at harvest. The per cent of pollen-collecting bees was determined five times and the rate of tripping by nectar collectors was measured eight times on only two randomly selected rows of subplots perpendicular to the line of colonies placed across the center of the field.

Other Conditions.- The field had been planted for hay production, and the growth was dense and rank, a condition generally considered unfavorable for seed production and bee visitation. Although there was little other alfalfa in bloom in the area during the main blossoming period of the experimental field, sweetclover along roadsides and irrigation ditches was an attractive and successful competitor. Injurious insects were kept at a low level, and weather conditions were excellent for bee activity and growth of the alfalfa.

Interference by bees other than those from colonies 
Table 2.-Seed yields and bee populations at various distances from bee colonies, Newton, Utah, 1951.

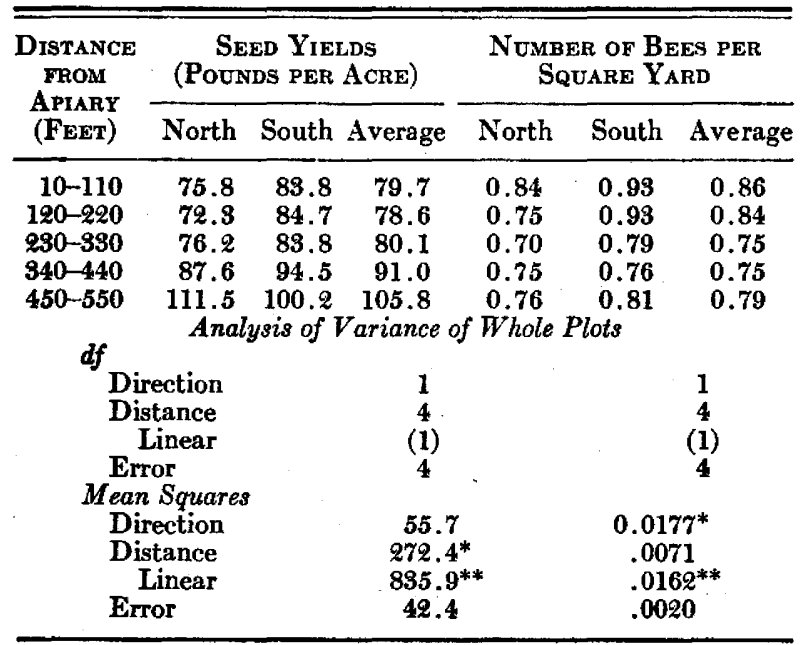

placed on the field did not appear to be an important factor. There were probably a few colonies of honey bees in the town of Newton, less than 2 miles south of the field, and a commercial apiary of about 60 colonies was known to be 2 miles to the southeast. Wild species of bees were scarce on the field.

Results. - The seasonal average population density for honey bees was 0.8 per square yard and for wild bees 0.013 . Only $0.28 \%$ of the honey bees collected pollen, and nectar collectors were seen to trip $0.93 \%$ of the flowers visited. Seed yields for all 80 subplots averaged 88 pounds per acre, unusually low for the area.

Correlations were calculated between distance and each of the following: honey bee populations, wild bee populations, tripped flowers, rate of tripping by nectar collectors, per cent of flowers forming seed pods, and seed yields, none of which were significant. Bee populations showed a significant linear relationship to distance from the colonies, but the differences were not significant (table 2). They were higher on the southern half of the field than on the northern half, but when studied separately by means of scatter diagrams, neither half showed any more relation to distance than when considered together. Bee populations appeared to be highest on the perimeter subplots, even though most of these were 10 feet or more from the edge of the field.

Honey bee populations during the peak of bloom from July 1 to 19 were correlated on a subplot basis with seed yields $\left(r=+0.228^{*}\right)$. At this low level of correlation, bee populations cannot be considered responsible for much of the variation in seed yields. However, none of the other factors measured showed any correlation with seed yields or with each other.

Howell, UTAH.-In 1955 and 1956 experiments were conducted on about 200 acres of alfalfa left for seed at Howell, about 50 miles west of Logan. The main objective was to determine what effect distances up to 1 mile from the apiary would have on the population of honey bees working alfalfa.

Experimental Area.-At this location several long, irregular, narrow alfalfa-seed fields grew in a north-south direction along one side of a road (fig. 2). One mile north

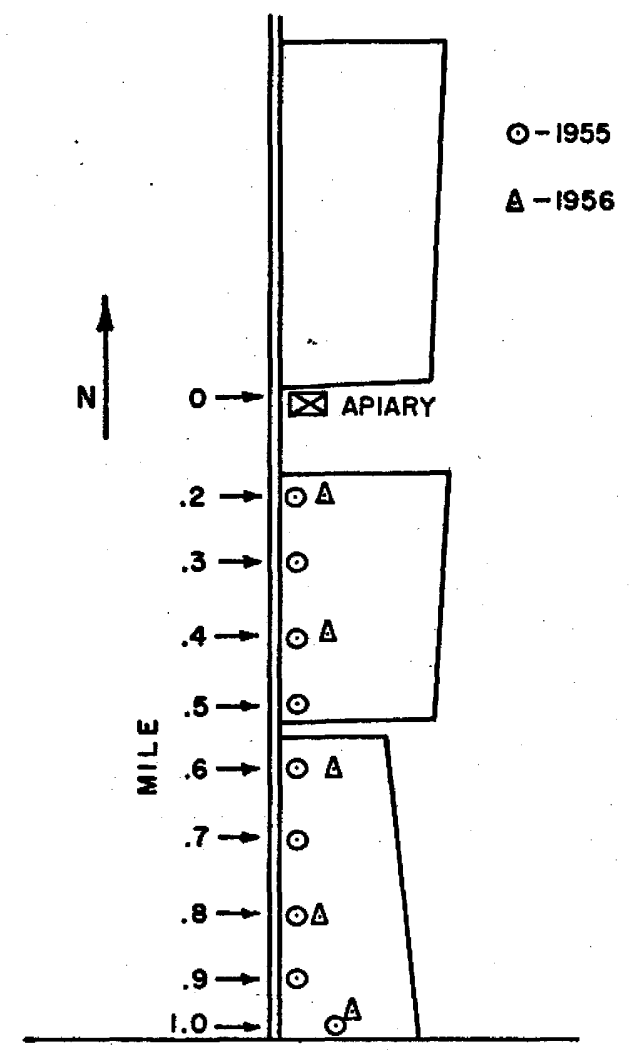

FIG. 2.-Diagram of experimental alfalfa seed fields showing sampling stations in 1955 and 1956, Howell, Utah.

of the southern edge of these fields, 160 colonies were placed in 1955 and 225 colonies in 1956. All other colonies in the area were situated more than a mile north of this apiary. Originally it was planned to take data in both directions from the bees, but the fields to the north were too far past the peak of bloom to attract enough bees to be comparable in 1955 and some of them were plowed up in 1956.

At the time measurements were taken in both seasons, these first-crop séed fields, totaling approximately 200 acres, provided most of the forage available to the bees. From 500 to 600 acres of hay alfalfa were within flight range to the north, east, and west, but only a little of this was coming into bloom in 1955 and none in 1956. Other sources of honey and pollen in the area were scarce, and only a meager crop of honey was harvested in both years.

Procedure.-In 1955 ten distances away from the bees were marked off at intervals of about 0.1 mile. The first sampling station was at zero distance, but the second station was almost 0.2 mile from the bees. In 1956 five distances were marked off at 0.2-mile intervals.

One serious drawback in using these fields was the lack of uniformity in growth and stage of bloom. This was more serious in 1955 than in 1956. However, measurements were taken in growth as nearly uniform as possible within a few feet of each measured distance.

In 1955 data collection was limited to counting the number of bees per square yard and determining the per cent of bees collecting pollen. In 1956 measurements were also made of soil surface temperature, relative humidity, 
Table 3.- Honey bee populations and per cent pollen collectors at different distances from the apiary. Howell, Utah, 1955.

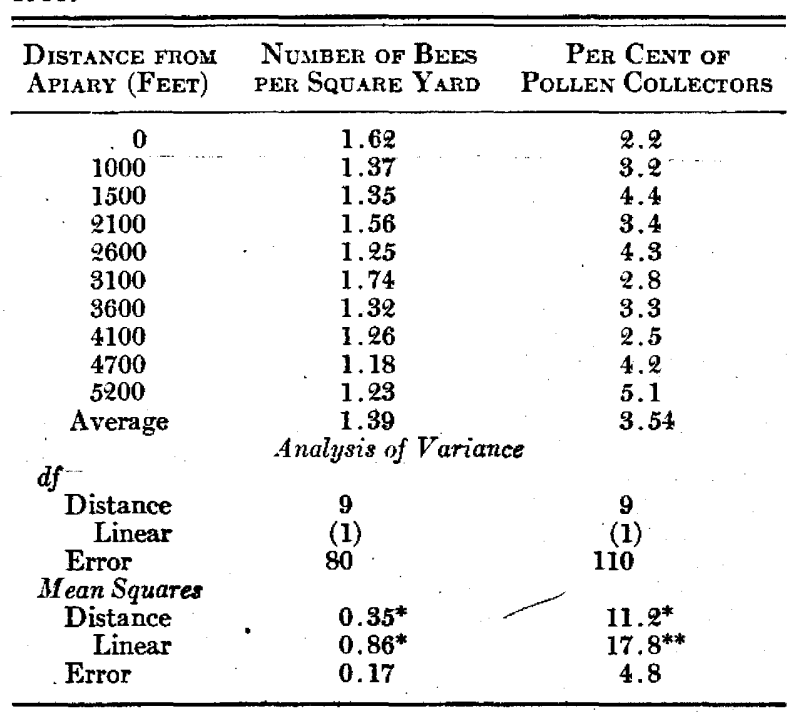

light reflected from a gray card on the ground, and the sugar concentration in nectar taken from the honey stomachs of bees.

In 1955 the counts were made by five observers over a period of 4 days during the peak of bloom and were made at each distance 7 to 12 times. In 1956 the counts were made by five observers over a 3-day period during peak bloom and were made at each station 19 times. The observers started at different distances on each day of counting.

In 1956 , ten sets of ecological measurements were made on each day and 15 bees were examined at each distance.

Results.-In 1955 (table 3) there was a gradual decrease in bee populations as the distance increased. The per cent of bees collecting pollen increased with the distance from the colonies, especially at the greatest distance.

In 1956 (table 4) there was a decrease in bee populations beyond the 3,000-foot distance. The per cent of pollen-collecting bees showed a gradual increase as the distance from the hives increased up to 4,000 feet and then dropped slightly at the last sampling zone.-

The sugar concentration of nectar taken from field bees, temperature, and light measurements all increased with distance from the hives, but the relative humidity dropped. Correlations between each of these four measurements and the per cent of pollen collectors are as follows:

Sugar concentration of neetar
Temperature
Light
Relative humidity

$$
\begin{gathered}
r \\
+0.774^{*} \\
+0.923^{* *} \\
+0.918^{*} \\
-0.594^{*}
\end{gathered}
$$

Discussion.-At first glance the different population densities at each location indicate that the influence of distance on bee populations depends on the number of bees on the field. If stratification of the bee population had appeared on fields with a small average number of bees, disappearing as the population increased, it would be easy to accept such a hypothesis. However, the fact that stratification was apparent only as the population in- creased suggests that other factors were involved

The data collected at Howell afford a glimpse of the complications present in work of this type. A decrease in bee population was observed as the distance from the apiary exceeded 3,000 feet. However, the ecological data collected in 1956 show differences in the environment around the plants, indicating a change in type of stand, which could have influenced the distribution of bees as much as distance from the hives. The reasons for these ecological differences are unknown, but unmeasured changes in soil fertility or moisture could be responsible.

The increase in per cent of pollen-collecting bees which was correlated with the changes in the ecological measurements, confirms previous observations that pollen collection in alfalfa is affected by the condition and environment of the plants. As light and temperature increased and relative humidity decreased, the plants became more attractive to pollen collectors. As the plants became more attractive to pollen collectors, they may have become less attractive to nectar collectors, presumably because of insufficient water for optimum nectar secretion. This possibility tends to confound the relationship between populations and distance.

The increase in sugar concentration of the nectar removed from bees was probably a reflection of the smaller population in combination with the lower relative humidity. With fewer bees to remove the nectar, it remained in the flowers, where it was subject to concentration by evaporation.

At Newton, under rather unfavorable conditions for seed production, no stratification of the bee population was observed within the distance available; and the seed yields increased slightly with distance from the hives. Although this is contrary to the findings of investigators studying red clover, the lack of correlation between the yields and most of the pollination data indicates that at these low levels of bee populations and seed yields, other variables between plots may have masked the effects of any possible differences in bee activities.

The correlation of bee populations during the peak of bloom with seed yields at Newton indicates that measurements taken within the period of maximum activity would be more likely to reveal existing relationships than would counts extended through the entire blooming pe-

\begin{tabular}{|c|c|c|c|c|c|c|}
\hline \multirow[b]{2}{*}{$\begin{array}{l}\text { Distance } \\
\text { Froy } \\
\text { APIART } \\
\text { (FEET) }\end{array}$} & \multirow[b]{2}{*}{$\begin{array}{c}\text { No. of } \\
\text { BEES PEE } \\
\text { SQ. Yv. }\end{array}$} & \multicolumn{2}{|c|}{ Per Cent of } & \multicolumn{3}{|c|}{$\begin{array}{c}\text { ENVIRonMant at } \\
\text { Flower LeVEL }\end{array}$} \\
\hline & & $\begin{array}{l}\text { Pollen } \\
\text { Cullectors }\end{array}$ & $\begin{array}{c}\text { Sugar in } \\
\text { Nectar } \\
\text { from Bee }\end{array}$ & $\begin{array}{c}\text { Humid- } \\
\text { ity } \\
\text { es }(\%)\end{array}$ & $\begin{array}{c}\text { Temper- } \\
\text { ture } \\
\text { (․). }\end{array}$ & $\begin{array}{c}\text { Light } \\
\text { (Ft.-C.) }\end{array}$ \\
\hline $\begin{array}{c}1000 \\
2000 \\
3000 \\
4000 \\
5000 \\
\text { Average }\end{array}$ & $\begin{array}{l}2.02 \\
1.74 \\
1.98 \\
1.74 \\
1.98 \\
1.75\end{array}$ & $\begin{array}{c}\mathbf{3 . 7} \\
5.8 \\
8.3 \\
11.4 \\
9.7 \\
7.78 \\
\text { Analyeis }\end{array}$ & $\begin{array}{r}48.9 \\
50.6 \\
52.3 \\
53.4 \\
54.9 \\
51.9 \\
\text { is of Varian }\end{array}$ & $\begin{array}{r}13.8 \\
18.6 \\
11.7 \\
9.8 \\
9.0 \\
11.5\end{array}$ & $\begin{array}{r}94.2 \\
96.0 \\
98.5 \\
100.6 \\
100.9 \\
98.0\end{array}$ & $\begin{array}{l}138.6 \\
139.2 \\
178.0 \\
199.8 \\
204.2 \\
170.6\end{array}$ \\
\hline $\begin{array}{l}d f \text { Treatment } \\
\text { Linear } \\
\text { Error } \\
\text { Mean Square }\end{array}$ & $\stackrel{4}{(1)}$ & $\stackrel{4}{(1)}$ & $\begin{array}{c}4 \\
(1) \\
220\end{array}$ & $\begin{array}{c}4 \\
145\end{array}$ & $\stackrel{4}{(1)}$ & $\stackrel{(1)}{(1)}$ \\
\hline $\begin{array}{l}\text { Treatment } \\
\text { Linear } \\
\text { Error }\end{array}$ & $\begin{array}{l}1.62^{* *} \\
4.2^{* *} \\
.995\end{array}$ & $\begin{array}{l}178.2^{* *} \\
588.5^{* *} \quad 1 \\
29.0\end{array}$ & $\begin{array}{c}300.8^{* *} \\
1180.9^{* *} \\
19.1\end{array}$ & $\begin{array}{l}124.5^{* *} \\
461.3^{* *} \\
19.5\end{array}$ & $\begin{array}{l}254^{* *} \\
978.0^{* *} \\
43.1\end{array}$ & $\begin{array}{c}97,875 \\
103,280^{*} \\
1,802\end{array}$ \\
\hline
\end{tabular}
riod. Consequently, in the experiments conducted after

Table 4.- Averaged data at progressive distances from the apiary. Howell, Utah, 1956. 
1951 counts were confined to the period with the highest bee populations.

The slightly larger populations and the significantly higher seed yields on the peripheral subplots at Newton may indicate that bees tend to accumulate along the borders of fields if they go beyond and find nothing on which to work. ${ }^{3}$ Increased attractiveness of bloom at the edge of the field was eliminated by avoiding the edge in the counts.

In view of the variable results reported here, it appears that the distribution of bees over an area is subject to modifying influences besides that of increasing distance from the colonies. Whether bees are collecting nectar or pollen, the availability of other food sources beyond the experimental field, and variations in the type of growth on the field may affect the distribution of field populations. It is important that all these factors be considered in attempts to determine the influence of distance on bee populations in the field. Because of the variations in these factors, the results reported do not provide sufficient evidence on which to base a recommendation for the most efficient distribution of colonies around alfalfa fields to be pollinated. However, it seems obvious that the closer colonies are to flowers where the bees are working, the less time and energy will be used in flying and the more pollination will be accomplished.

\section{References Cimed}

Braun, E., R. M. MacVicar, D. R. Gibson, P. Pankiw, and J. Guppy. 1953. Studies in red clover seed production. Part II. Canadian Jour. Agric. Sci. 33 : 437-47.

MacVicar, R. M., E. Braun, D. R. Gibson, and C. A. Jamieson. 1952. Studies in red clover seed production. Sci. Agric. 32:67-80.

Vansell, G. H., 1951. Use of honey bees in alfalfa seed production. U. S. Dept. Agric. Circ. 876, 11 pp.

Walstrom, R. J. 1958. Effects of flight distances from honey bee colonies on red clover seed yields. Jour. Econ. Ent. 51: 64-7.

Walstrom, R. J., F. B. Paddock, O. W. Park, and C. P. Wilsie. 1951. Red clover pollination at various distances from honey bee colonies. Report Iowa State Apiarist for 1950, pp. 51-2.

Zivov, V., and S. Skvorkov. 1951. (Title unknown) Sel. Seed Gr. 18(6): 63-4 (Moscow) (In Russian). Abstract in Bee World 34: 104, (1953).

F. E. Todd, in correspondence, reports a simular accumulation of bees at the ends of rows of cantaloupes in Arizona.

\section{Reprinted from the \\ Journal of Economic EnTomology}

Vol. 53, No. 1, February, 1960

pp. $56-60$ 